\title{
A NECESSARY AND SUFFICIENT CONDITION FOR THE CONVEXITY OF THE ONE-PARAMETER GENERALIZED INVERSE TRIGONOMETRIC SINE FUNCTION ACCORDING TO POWER MEAN
}

\author{
MiaO-Ying Hong, MiaO-Kun Wang And Yu-Ming ChU*
}

Abstract. In the article, we present a necessary and sufficient condition such that the one-parameter generalized inverse trigonometric sine function is convex with respect to power mean. As a consequence, we provide the necessary and sufficient condition for the concavity of the oneparameter generalized trigonometric sine function according to power mean.

Mathematics subject classification (2020): 33B10, 26D07, 26A51, 26E60.

Keywords and phrases: Generalized trigonometric sine function, generalized inverse trigonometric sine function, power mean, convexity.

\section{REFERENCES}

[1] I. Abbas Baloch, A. A. Mughal, Y.-M. Chu, A. U. Haq and M. De La Sen, A variant of Jensen-type inequality and related results for harmonic convex functions, AIMS Math., 5, 6 (2020), 6404-6418.

[2] T. Abdeljawad, S. Rashid, Z. Hammouch And Y.-M. CHU, Some new local fractional inequalities associated with generalized $(s, m)$-convex functions and applications, Adv. Difference Equ., 2020 (2020), Article 406, 27 pages.

[3] T. Abdeljawad, S. Rashid, H. Khan And Y.-M. Chu, On new fractional integral inequalities for p-convexity within interval-valued functions, Adv. Difference Equ., 2020 (2020), Article 330, 17 pages.

[4] M. Adil Khan, M. Hanif, Z. A. Khan, K. Ahmad and Y.-M. Chu, Association of Jensen's inequality for s-convex function with Csiszár divergence, J. Inequal. Appl., 2019 (2019), Article 162, 14 pages.

[5] M. Adil Khan, J. PEČARIĆ And Y.-M. CHU, Refinements of Jensen's and McShane's inequalities with applications, AIMS Math., 5, 5 (2020), 4931-4945.

[6] P. AgArwal, M. KadAKal, İ. İşCAN And Y.-M. CHU, Better approaches for $n$-times differentiable convex functions, Mathematics, 8, 6 (2016), Article 95011 pages.

[7] G. D. Anderson, M. K. Vamanamurthy and M. Vuorinen, Conformal Invariants, Inequalities, and Quasiconformal Maps, John Wiley \& Sons, New York, 1997.

[8] G. D. Anderson, M. K. Vamanamurthy And M. Vuorinen, Generalized convexity and inequalities, J. Math. Anal. Appl., 335, 2 (2007), 1294-1308.

[9] M. U. Awan, N. Akhtar, S. Iftikhar, M. A. Noor And Y.-M. Chu, New Hermite-Hadamard type inequalities for n-polynomial harmonically convex functions, J. Inequal. Appl., 2020 (2020), Article 125, 12 pages.

[10] M. U. Awan, N. Akhtar, A. Kashuri, M. A. Noor And Y.-M. Chu, 2D approximately reciprocal $\rho$-convex functions and associated integral inequalities, AIMS Math., 5, 5 (2020), 4662-4680.

[11] M. U. Awan, S. Talib, Y.-M. Chu, M. A. Noor And K. I. Noor, Some new refinements of Hermite-Hadamard-type inequalities involving $\Psi_{k}$-Riemann-Liouville fractional integrals and applications, Math. Probl. Eng., 2020 (2020), Article ID 3051920, 10 pages.

[12] M. U. Awan, S. Talib, A. Kashuri, M. A. Noor And Y.-M. Chu, Estimates of quantum bounds pertaining to new q-integral identity with applications, Adv. Difference Equ., 2020 (2020), Article 424,15 pages. 
[13] M. U. Awan, S. Talib, M. A. Noor, Y.-M. Chu, K. I. Noor, Some trapezium-like inequalities involving functions having strongly n-polynomial preinvexity property of higher order, J. Funct. Spaces, 2020 (2020), Article ID 9154139, 9 pages.

[14] Ö. BAKşI, P. GuRKa, J. LANG AND O. MÉndeZ, Basis properties of Lindqvist-Peetre functions on $L^{r}(0,1)^{n}$, Rev. Mat. Complut., 30, 1 (2017), 1-12.

[15] Á. BARICZ, Convexity of the zero-balanced Gaussian hypergeometric functions with respect to Hölder means, JIPAM. J. Inequal. Pure Appl. Math., 8, 2 (2007), Article 40, 9 pages.

[16] Á. BARICZ, B. A. BHAYO AND R. KLÉN, Convexity properties of generalized trigonometric and hyperbolic functions, Aequationes Math., 89, 3 (2015), 473-484.

[17] Á. BARICZ, B. A. BhAYo AND T. K. PogÁNy, Functional inequalities for generalized inverse trigonometric and hyperbolic functions, J. Math. Anal. Appl., 417, 1 (2014), 244-259.

[18] Á. BARICZ, B. A. BHAYO AND M. VuORINEN, Turán inequalities for generalized inverse trigonometric functions, Filomat, 29, 2 (2015), 303-313.

[19] B. A. Bhayo, Power mean inequalities generalized trigonometric functions, Math. Vesnik, 67, 1 (2015), 17-25.

[20] B. A. BHAYO AND M. VuORINEN, On generalized trigonometric functions with two parameters, J. Approx. Theory, 164, 10 (2012), 1415-1426.

[21] R. J. Biezuner, G. Ercole And E. M. Martins, Computing the first eigenvalue of the pLaplacian via the inverse power method, J. Funct. Anal., 257, 1 (2009), 243-270.

[22] P. J. Bushell AND D. E. Edmunds, Remarks on generalized trigonometric functions, Rocky Mountain J. Math., 42, 1 (2012), 25-57.

[23] Y.-M. ChU, M. U. Awan, M. Z. Javad AND A. W. Khan, Bounds for the remainder in Simpson's inequality via n-polynomial convex functions of higher order using Katugampola fractional integrals, J. Math., 2020 (2020), Article ID 4189036, 10 pages.

[24] Y.-M. CHU, Y.-F. QIU AND M.-K. WANG, Hölder mean inequalities for the complete elliptic integrals, Integral Transforms Spec. Funct., 23, 7 (2012), 521-537.

[25] Y.-M. ChU, S.-L. QIU AND M.-K. WANG, Sharp inequalities involving the power mean and complete elliptic integral of the first kind, Rocky Mountain J. Math., 43, 5 (2013), 1489-1496.

[26] Y.-M. ChU, M.-K. WANG, Y.-P. JIANG AND S.-L. QIU, Concavity of the complete elliptic integrals of the second kind with respect to Hölder means, J. Math. Anal. Appl., 395, 2 (2012), 637-642.

[27] Y.-M. ChU AND T.-H. ZHAO, Concavity of the error function with respect to Hölder means, Math. Inequal. Appl., 19, 2 (2016), 589-595.

[28] P. DRÁBEK AND R. MANÁSEVICH, On the closed solution to some p-Laplacian nonhomogeneous eigenvalue problems, Differential Integral Equations, 12, 6 (1999), 773-788.

[29] D. E. Edmunds, P. Gurka And J. LANG, Properties of generalized trigonometric functions, J. Approx. Theory, 164, 1 (2012), 47-56.

[30] H. Ge-Jile, S. Rashid, M. A. Noor, A. Suhail and Y.-M. Chu, Some unified bounds for exponentially tgs-convex functions governed by conformable fractional operators, AIMS Math., 5, 6 (2020), 6108-6123.

[31] S.-Y. Guo, Y.-M. Chu, G. Farid, S. Mehmood and W. Nazeer, Fractional Hadamard and Fejér-Hadamard inequaities associated with exponentially $(s, m)$-convex functions, J. Funct. Spaces, 2020 (2020), Article ID 2410385, 10 pages.

[32] G.-J. HAI AND T.-H. ZHAO, Monotonicity properties and bounds involving the two-parameter generalized Grötzsch ring function, J. Inequal. Appl., 2020 (2020), Article 66, 17 pages.

[33] S. Hussain, J. Khalid And Y.-M. Chu, Some generalized fractional integral Simpson's type inequalities with applications, AIMS Math., 5, 6 (2020), 5859-5883.

[34] A. Iqbal, M. Adil Khan, N. Mohammad, E. R. Nwaeze and Y.-M. Chu, Revisiting the Hermite-Hadamard integral inequality via a Green function, AIMS Math., 5, 6 (2020), 6087-6107.

[35] A. IQbal, M. Adil Khan, S. Ullah And Y.-M. Chu, Some new Hermite-Hadamard-type inequalities associated with conformable fractional integrals and their applications, J. Funct. Spaces, 2020 (2020), Article ID 9845407, 18 pages.

[36] W.-D. JiAnG, M.-K. WANG, Y.-M. ChU, Y.-P. JIANG AND F. QI, Convexity of the generalized sine function and the generalized hyperbolic sine function, J. Approx. Theory, 174 (2013), 1-9.

[37] H. Kalsoom, M. Idrees, D. Baleanu And Y.-M. Chu, New estimates of $q_{1} q_{2}$-Ostrowski-type inequalities within a class of n-polynomial prevexity of function, J. Funct. Spaces, 2020 (2020), Article ID 3720798, 13 pages. 
[38] D. B. KARP AND E. G. PRILEPKINA, Parameter convexity and concavity of generalized trigonometric functions, J. Math. Anal. Appl., 421, 1 (2015), 370-382.

[39] S. Khan, M. Adil KHAn And Y.-M. CHU, Converses of the Jensen inequality derived from the Green functions with applications in information theory, Math. Methods Appl. Sci., 2020, 43, 5 (2020), 2577-2587.

[40] Y. KHURShid, M. Adil KHAN AND Y.-M. CHU, Conformable fractional integral inequalities for $G G$ - and GA-convex function, AIMS Math., 5, 5 (2020), 5012-5030.

[41] Y. Khurshid, M. AdIL KHAN AND Y.-M. CHU, Conformable integral version of HermiteHadamard-Fejér inequalities via $\eta$-convex functions, AIMS Math., 5, 5 (2020), 5106-5120.

[42] R. KLÉn, M. VuORUnEN AND X.-H. ZHANG, Inequalities for the generalized trigonometric and hyperbolic functions, J. Math. Anal. Appl., 409, 1 (2014), 521-529.

[43] H. KoBAyASHI AND S. TAKEUCHI, Applications of generalized trigonometric functions with two parameters, Commun. Pure Appl. Anal., 18, 3 (2019), 1509-1521.

[44] J. LANG AND D. Edmunds, Eigenvalues, Embeddings and Generalised Trigonometric Functions, Springer, Heidelberg, 2011.

[45] P. LindQVist, Some remarkable sine and cosine functions, Ricerche Mat., 44, 2 (1995), $269-290$.

[46] P. Lindevist And J. PeEtre, $p$-arclength of the $q$-circle, Math. Student, 72, 1-4 (2003), $139-145$.

[47] E. NEUMAN, Inequalities involving hyperbolic functions and trigonometric function II, Bull. Int. Math. Virtual Inst., 6, 2 (2016), 209-217.

[48] H.-X. QI, M. Yussouf, S. Mehmood, Y.-M. ChU AND G. FARID, Fractional integral versions of Hermite-Hadamard type inequality for generalized exponentially convexity, AIMS Math., 5, 6 (2020), 6030-6042.

[49] W.-M. QIAN, W. ZHANG AND Y.-M. CHU, Bounding the convex combination of arithmetic and integral means in terms of one-parameter harmonic and geometric means, Miskolc Math. Notes, 20, 2 (2019), 1157-1166.

[50] S. Rashid, R. Ashraf, M. A. Noor, K. I. Noor AND Y.-M. CHU, New weighted generalizations for differentiable exponentially convex mapping with application, AIMS Math., 5, 4 (2020), 35253546.

[51] S. RAShid, İ. İşCAN, D. BALEANU AND Y.-M. CHU, Generation of new fractional inequalities via $n$ polynomials s-type convexity with applications, Adv. Difference Equ., 2020 (2020), Article 264, 20 pages.

[52] S. RASHID, F. JARAD AND Y.-M. CHU, A note on reverse Minkowski inequality via generalized proportional fractional integral operator with respect to another function, Math. Probl. Eng., 2020 (2020), Article ID 7630260, 12 pages.

[53] S. Rashid, F. Jarad, H. Kalsoom And Y.-M. ChU, On Pólya-Szegö and Ćebyšev type inequalities via generalized $k$-fractional integrals, Adv. Difference Equ., 2020 (2020), Article ID 125, 18 pages.

[54] S. RAshid, A. Khalid, G. Rahman, K. S. NisAR AND Y.-M. CHU, On new modifications governed by quantum Hahn's integral operator pertaining to fractional calculus, J. Funct. Spaces, 2020 (2020), Article ID 8262860, 12 pages.

[55] J.-M. Shen, S. RAshid, M. A. Noor, R. Ashraf And Y.-M. Chu, Certain novel estimates within fractional calculus theory on time scales, AIMS Math., 5, 6 (2020), 6073-6086.

[56] J.-M. Shen, Z.-H. YAng, W.-M. Qian, W. Zhang AND Y.-M. CHU, Sharp rational bounds for the gamma function, Math. Inequal. Appl., 23, 3 (2020), 843-853.

[57] Y.-Q. Song, Y.-M. CHU, B.-Y. LiU And M.-K. WANG, A note on generalized trigonometric and hyperbolic functions, J. Math. Inequal., 8, 3 (2014), 635-642.

[58] M.-B. SUn AND Y.-M. CHU, Inequalities for the generalized weighted mean values of $g$-convex functions with applications, Rev. R. Acad. Cienc. Exactas Fís. Nat. Ser. A Mat. RACSAM, 114, 4 (2020), Article 172, 12 pages.

[59] S. TAKEUCHI, Generalized Jacobian elliptic functions and their application to bifurcation problems associated with p-Laplacian, J. Math. Anal. Appl., 385, 1 (2012), 24-35.

[60] G.-D. WANG, The inverse hyperbolic tangent function and Jacobian sine function, J. Math. Anal. Appl., 448, 1 (2017), 498-505.

[61] M.-K. Wang, H.-H. Chu And Y.-M. Chu, Precise bounds for the weighted Hölder mean of the complete p-elliptic integrals, J. Math. Anal. Appl., 480, 2 (2019), Article ID 123388, 9 pages. 
[62] M.-K. WANG, Y.-M. ChU AND Y.-P. JIANG, Ramanujan's cubic transformation inequalities for zero-balanced hypergeometric functions, Rocky Mountain J. Math., 46, 2 (2016), 679-691.

[63] M.-K. WANG, H.-H. CHU, Y.-M. LI AND Y.-M. CHU, Answers to three conjectures on convexity of three functions involving complete elliptic integrals of the first kind, Appl. Anal. Discrete Math., 14, 1 (2020), 255-271.

[64] M.-K. WANG, Y.-M. ChU, Y.-M. Li AND W. ZHANG, Asymptotic expansion and bounds for complete elliptic integrals, Math. Inequal. Appl., 23, 3 (2020), 821-841.

[65] M.-K. WANG, Y.-M. ChU, S.-L. QIU AND Y.-P. JIANG, Convexity of the complete elliptic integrals of the first kind with respect to Hölder means, J. Math. Anal. Appl., 388, 2 (2012), 1141-1146.

[66] M.-K. WANG, Z.-Y. HE AND Y.-M. CHU, Sharp power mean inequalities for the generalized elliptic integral of the first kind, Comput. Methods Funct. Theory, 20, 1 (2020), 111-124.

[67] M.-K. WANG, W. ZHANG AND Y.-M. CHU, Monotonicity, convexity and inequalities involving the generalized elliptic integrals, Acta Math. Sci., 39B, 5 (2019), 1440-1450.

[68] L. Xu, Y.-M. Chu, S. Rashid, A. A. El-Deeb AND K. S. Nisar, On new unified bounds for a family of functions with fractional q-calculus theory, J. Funct. Spaces, 2020 (2020), Article ID 4984612, 9 pages.

[69] P.-Y. YAn, Q. Li, Y.-M. ChU, S. MukhtAR And S. WAHEed, On some fractional integral inequalities for generalized strongly modified h-convex function, AIMS Math., 5, 6 (2020), 6620-6638.

[70] X.-Z. Yang, G. Farid, W. NAZeer, Y.-M. Chu and C.-F. Dong, Fractional generalized Hadamard and Fejér-Hadamard inequalities for m-convex function, AIMS Math., 5, 6 (2020), 63256340.

[71] X.-H. Zhang, G.-D. WANG And Y.-M. ChU, Convexity with respect to Hölder mean involving zero-balanced hypergeometric functions, J. Math. Anal. Appl., 353, 1 (2009), 256-259.

[72] T.-H. ZhaO, Z.-Y. He AND Y.-M. ChU, On some refinements for inequalities involving zerobalanced hypergeometric function, AIMS Math., 5, 6 (2020), 6479-6495.

[73] T.-H. ZHAO, L. SHI AND Y.-M. CHU, Convexity and concavity of the modified Bessel functions of the first kind with respect to Hölder means, Rev. R. Acad. Cienc. Exactas Fís. Nat. Ser. A Mat. RACSAM, 114, 2 (2020), Article 96, 14 pages.

[74] T.-H. ZHAO, M.-K. WANG AND Y.-M. CHU, A sharp double inequality involving generalized complete elliptic integral of the first kind, AIMS Math., 5, 5 (2020), 4512-4528.

[75] S.-S. Zhou, S. Rashid, F. JARAD, H. Kalsoom And Y.-M. Chu, New estimates considering the generalized proportional Hadamard fractional integral operators, Adv. Difference Equ., 2020 (2020), Article ID 275, 15 pages. 